第 20 回 日本臨床薬理学会年会 1999 年 12 月 3 4 日 横浜 シンポジウム $2:$ 医薬品の適応外使用

\title{
1. 日本臨床薬理学会による調查
}

\begin{tabular}{|c|c|c|c|c|c|c|c|c|}
\hline 合 & 遦 & 一** & 猿 & 田 & 享 & 男* & 新 & 博 \\
\hline 牧 & 环 & 巳* & 江 & 口 & 研 & 二* & 小野寺 & 昭 \\
\hline & & 茂* & 武 & 谷 & 雄 & 二* & 増 田 & 寛次郎 \\
\hline & & 子* & 八 & 木 & 剛 & 平* & & \\
\hline
\end{tabular}

画期的な医薬品の開発は人類全体の福祉に貢献す るものであり、その内滑な推進が期待されている。 しかし、こうした医薬品開発をもつぱら新規の医薬 品に期待するとなると、その有効性の証明と十分な 安全性の確認のためには長期にわたる基礎研究や臨 床試験と、莫大な開発経費が必要となる。一方、市 販されている医薬品は、すでに、ある疾患を対象と して有効性と有害反応に関する十分な情報が得られ ている訳だが、これらの開発中または市販後に、適 応とされた疾患以外の疾患での有効性が認められる ことがある。これらは，通常の認可を受けなければ 適応外のままで臨床で使われることになる。しかし、 そうした適応外使用は、しばしば臨床の現場で問題 にされている。これら適応外使用の問題点を Table 1 にまとめた。

本学会学術委員会（猿田享男委員長）は、各分野 の専門家がこうした適応外使用に関してぞのような 意見を持っているかについて調查した。

[方法］まず、本学会員に限定せずに拡大学術委員 会を構成した。各委員は、医学論文などの情報を根 拠に、現在適応外使用されている医菜品の実例を挙 げた。さらに 16 分野における尃門家を、原則とし て各々 5 名選出した (Table 2)。これらの専門家に は、適店拡大が必要な候補薬物の各々に対して、そ

*日本臨床薬理学会拡大学術委員会

的聖マリアンナ医科大学難病治療研究センター

于 216-8512 川崎市宮前区菅生 2-16-1
の必要度を 3 段階で判定して頂いた (Table 3)。 [結果] 計 86 名の専門家に依頼し、83 名より回 答を得た。候補となった疾患と薬物の組合せは、 合計 202 であったが、専門家が国内的・国際的に ほぼ確立し、十分な有効性と有用性を示す正確な データがあるとしたものは 90 にのぼった (Table 4)。

[考察・結論］今回、専門医を対象とした調査に より、わが国では適応外だが国際的にはある程度 評価が定まっている治療法が少なくないことが明 らかになった。こうした成績もあり、現在厚生省 は、津谷班や健康政策局研究開発振興課長および 医薬安全局審査管理課長通知「適応外使用に係る 医療用医薬品の扱いについて」(平成 11 年 2 月 1 日）で対応している。しかし専門学会や製薬企業 の対応も不十分なことから、必ずしも十分に活用 されていない。

こうした適応拡大に加え、添付文書上の用量・ 用法に変更についても同様の手続きで可能とも考 えられ、今後各専門学会の積極的な取り組みと企 業および厚生省の柔軟な対応により、本制度の利 用が活発化することを望みたい。

参考文献

1）猿田享男、他: 臨床薬理 $28: 729-741,1997$ 
Table 1. 適応外使用の問題点

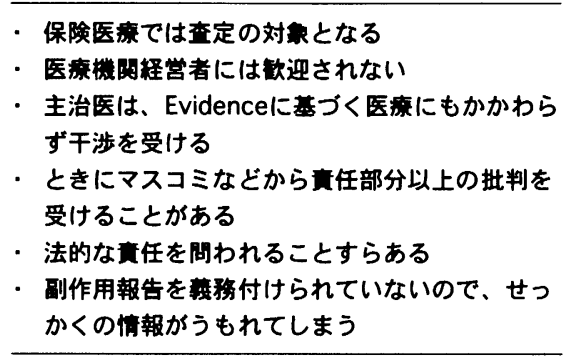

Table 2. 適応拡大調查協力者

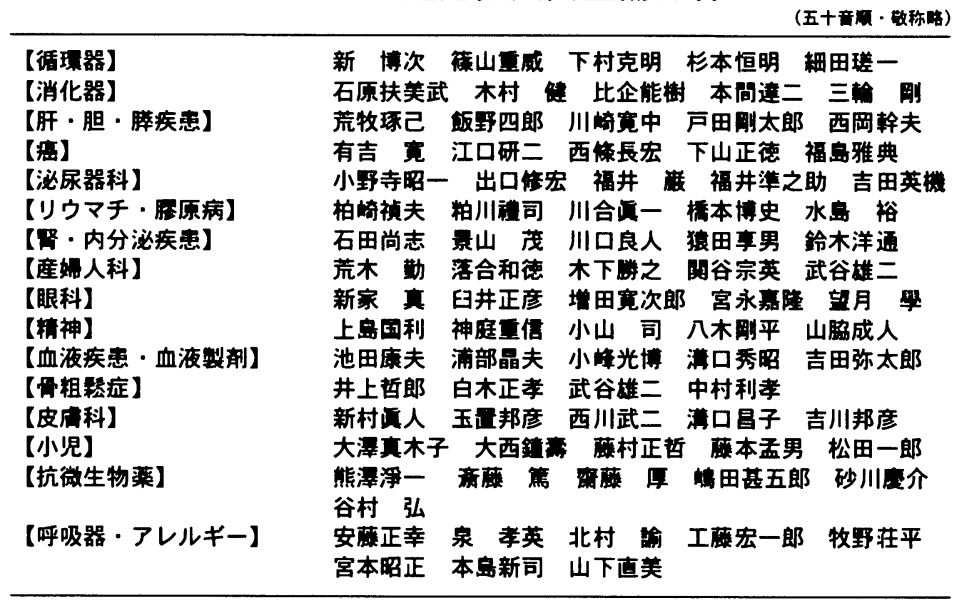

Table 3. 適応桩大候捕菜用の必要度の判定基準

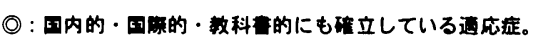

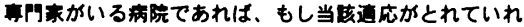
ば(实咸は現在もそうであるが)必ず使用する例がある 莱物・治洋法と通応应。

○：国内的・四繁的にほほ琟立し、その有奻性と有用性を示 す正磪なデータがある。100\%ではないが、多くの苹用

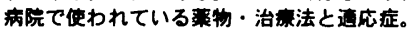

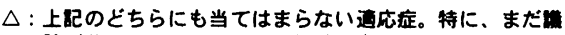

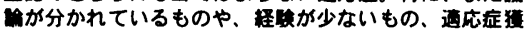
得のため少なくとも今後補完的治卧か必要と思われる 来物・治絜法。
Table 4. 適応拡大調查の集㖕結果

回答事 83名/86名 $=96.5 \%$

委買会の挙げた候㭪（血合せ） 202

· 全员か○か○ 90

・少なくとも1名が $\triangle 112$

·全员か② 21

・1人を除き(2) 21

・2人を除き○) 23 